\title{
A NEW REPORT CONFIRMING THE PRESENCE OF BENNETT'S STINGRAY, HEMITRYGON BENNETTII (ELASMOBRANCHII: MYLIOBATIFORMES: DASYATIDAE), FROM THE WESTERN BAY OF BENGAL
}

\author{
Menon MUKTHA ${ }^{1}$, K.V. AKHILESH ${ }^{2}$, S. SUKUMARAN ${ }^{3}$, and S.J. KIZHAKUDAN ${ }^{4}$ \\ ${ }^{1} I C A R-C e n t r a l$ Marine Fisheries Research Institute, Visakhapatnam Regional Centre, Andhra Pradesh, India \\ ${ }^{2}$ ICAR-Central Marine Fisheries Research Institute, Mumbai Research Centre, Maharashtra, India \\ ${ }^{3}$ ICAR-Central Marine Fisheries Research Institute, Head Quarters, Kochi, Kerala, India \\ ${ }^{4} I C A R-C e n t r a l$ Marine Fisheries Research Institute, Chennai Research Centre, Tamil Nadu, India
}

\begin{abstract}
Muktha M., Akhilesh K.V., Sukumaran S., Kizhakudan S.J. 2019. A new report confirming the presence of Bennett's stingray, Hemitrygon bennettii (Elasmobranchii: Myliobatiformes: Dasyatidae), from the western Bay of Bengal. Acta Ichthyol. Piscat. 49 (1): 101-108.
\end{abstract}

\begin{abstract}
The occurrence of Bennett's stingray, Hemitrygon bennettii (Müller et Henle, 1841), is confirmed from Indian waters, based on a single male specimen $(370 \mathrm{~mm} \mathrm{DW})$ collected from Visakhapatnam, western Bay of Bengal on 28 January 2017. Existing, updated reports on the distribution of the species, places it in the IndoPacific region with the western limit being the Strait of Malacca. With the presently confirmed occurrence from the western Bay of Bengal, the known distribution of the species extends further westwards to the Indian east coast, although it is likely to be a rare species in Indian waters.
\end{abstract}

Keywords: Dasyatidae, taxonomy, Indian Ocean, India, batoids

\section{INTRODUCTION}

The genus Hemitrygon Müller et Henle, 1838 was 'resurrected' by Last et al. (2016b) in a major revision of the family Dasyatidae and currently contains at least 10 species (Last et al. 2016a, 2016b): Hemitrygon akajei (Müller et Henle, 1841) from the Western Pacific, Hemitrygon bennettii (Müller et Henle, 1841) from the Indo-West Pacific, Hemitrygon fluviorum (Ogilby, 1908) from Australia and New Guinea, Hemitrygon izuensis (Nishida et Nakaya, 1988) from the western North Pacific, Hemitrygon laevigata (Chu, 1960) from the western North Pacific, Hemitrygon laosensis (Roberts et Karnasuta, 1987) from south-east Asia, Hemitrygon longicauda (Last et White, 2013) from West Papua and Indonesia, Hemitrygon navarrae (Steindachner, 1892) from the western Pacific, Hemitrygon parvonigra (Last et White, 2008) from the eastern Indian Ocean and western Pacific; Hemitrygon sinensis (Steindachner, 1892) from China to South Korea (Last et al. 2016a; Fricke et al. 2018).

Bennett's stingray, Hemitrygon bennettii, is a poorly known stingray distributed in the Indo-Pacific and is considered to be most abundant in the northwestern Pacific Ocean region. However, its westernmost distribution limit in the Indian Ocean is unknown, with possible distribution range suggested from Japan to India (Valenti 2016). The species can grow to a maximum size of $610 \mathrm{~mm}$ disc width (DW) and it occurs mostly at depths of $25-36 \mathrm{~m}$, in coastal soft bottom habitats (Last et al. 2016a, Weigmann 2016)

Several Indian studies have reported/listed $H$. bennettii from Indian waters (Day 1878, Day 1889, Misra 1947, 1952, 1969, Talwar and Kacker 1984). However, recent reports are mostly lacking or misidentified. In a recent checklist of chondrichthyans from India, Akhilesh et al. (2014) listed the occurrence of $H$. bennettii in India as "Needs Confirmation" category, requiring additional specimens along with genetic data, due to the absence of "correctly" identified material in collections in India matching that of H. bennettii and possible misidentification in recent studies/ reports from the region. Furthermore, several misidentified photos have been deposited from India or nearby regions as " $H$. bennettii" in popular websites" and even FishBase (Froese and Pauly 2018), which are possibly Maculabatis sp. or Himantura sp. Hemitrygon bennettii has been reported from the Persian Gulf and Sea of Oman by Assadi and Dehghani (1997) and Vossoughi and Vosoughi (1999). Reports of the species from Oman Sea, Persian Gulf and Sri Lanka (Anonymous 2018) could not be verified due to

\footnotetext{
" Correspondence: Dr K.V. Akhilesh, ICAR, Central Marine Fisheries Research Institute, Mumbai Research Centre, 2nd Floor, CIFE Old Campus, Fisheries University Road, Versova, Mumbai - 400061, Maharashtra, India, phone: +91 7678036389, e-mail: (AKV) akhikv@gmail.com, (MM) muktham@gmail.com, (SS)sukumaransandhya@yahoo.com, (SJK) jkshoba@gmail.com.

${ }^{* *}$ http://www.keralamarinelife.in/view.aspx? searchid $=1889$.
} 
lack of easily accessible photographic and morphometric evidence, however, authors positively assume Sri Lankan record could be reliable.

In the monumental work, 'Rays of the world', Last et al. (2016a) too, restricted the western distribution limit of $H$. bennettii to the Coral Triangle region (Strait of Malacca) only. In this study, we confirm the presence of Hemitrygon bennettii along the east coast of India using morphometrics, photographs and COI data, based on a single male specimen of $370 \mathrm{~mm}$ DW collected from Visakhapatnam Fisheries Harbour, Andhra Pradesh, India on 28 January 2017 and landed as trawl bycatch from the western Bay of Bengal.

\section{MATERIALS AND METHODS}

A single male specimen of Hemitrygon bennettii was collected from Visakhapatnam Fishing Harbour (Fig. 1) on 28 January 2017, landed by fishery trawl boat which had fished in areas within $100 \mathrm{~m}$ depth off Visakhapatnam within the Indian EEZ. The specimen was brought to the laboratory in fresh condition, photographs were taken and tissue samples were collected for genetic analyses. The specimen was identified following Last et al. (2016a). The disc width (DW) in mm and total weight ( $\mathrm{g}$ ) of the specimen was recorded. Tissue samples were collected and preserved in $95 \%$ ethanol for further DNA studies. Following this, the specimen was preserved in $10 \%$ formalin. All further morphometric measurements were taken of the preserved specimen. Morphometric measurements follow Jacobsen and Bennett (2009), Smith et al. (2009), and Muktha et al. (2018).

Molecular analysis. DNA extraction was carried out using a standard phenol/chloroform extraction protocol. A 650 bp region of the Cytochrome $\mathrm{C}$ oxidase 1 was amplified using a universal primer (Folmer et al. 1994). The composition of PCR reaction mixture was; $10 \mathrm{mM}$ Tris- $\mathrm{HCl}, \mathrm{pH} 8.3$, $50 \mathrm{mM} \mathrm{KCl}, 1.5 \mathrm{mM} \mathrm{MgCl}, 200 \mu \mathrm{M}$ of each dNTP, 0.2 $\mu \mathrm{M}$ of each oligonucleotide, 1 unit of Taq DNA polymerase and $50 \mathrm{ng}$ of template DNA. The fragments were amplified using Biorad T100 thermocycler (Biorad USA) and the PCR conditions were; initial denaturation at $94^{\circ} \mathrm{C}$ for 4 minutes followed by 33 cycles of; denaturation at $94^{\circ} \mathrm{C}$ for $30 \mathrm{~s}$, annealing at $42^{\circ} \mathrm{C}$ for $30 \mathrm{~s}$, extension at $72^{\circ} \mathrm{C}$ for $40 \mathrm{~s}$ and a final extension at $72^{\circ} \mathrm{C}$ for $7 \mathrm{~min}$. Purification of the PCR products was carried out using Qiagen PCR purification kit and sequencing was carried out with BigDye Terminator Sequencing Ready Reaction v 3.0 kit (Applied Biosystems) using the primers. A 620 bp region of the Cytochrome C Oxidase gene was amplified and the sequence submitted to NCBI, GenBank with accession number MH329420.

The sequence of cytochrome c oxidase 1 (COI) $(620$ bases) was aligned with available sequences retrieved from GenBank of other species of the genus, Hemitrygon bennettii, H. fluviorum, H. akajei, H. izuensis, H. parvonigra, $H$. laevigata, and $H$. longicauda using Clustal $\mathrm{W}$ in MEGA 6. A neighbor joining tree was constructed using UPGMA method with 1000 bootstraps. Tree topology was also tested using maximum likelihood, maximum parsimony and neighbour-joining methods. The COI tree was then rooted with the sequence of Scoliodon laticaudus Müller et Henle, 1838 retrieved from GenBank. Genetic divergence between all the species was analysed using Kimura 2 p distance values in MEGA 6. The current specimen is deposited in the fish collections of the Visakhapatnam Research Centre of ICARCentral Marine Fisheries Research Institute (CMFRI), India with accession number CMFRI V-D.1.

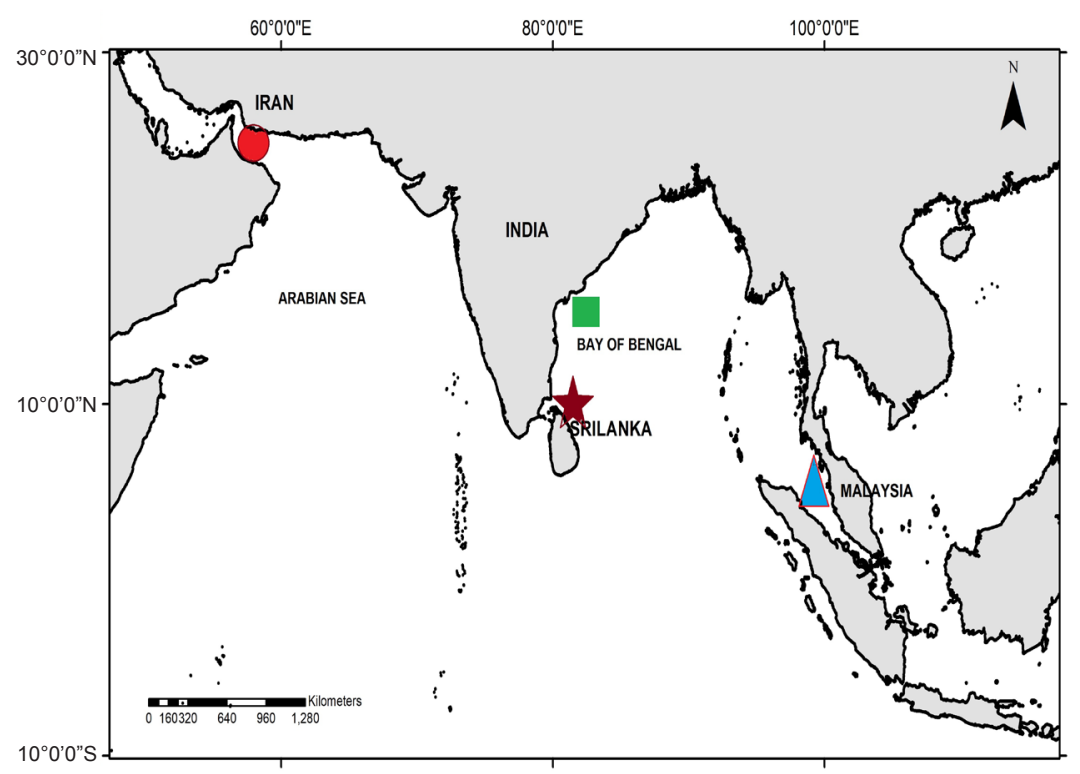

Fig. 1. Map showing Visakhapatnam (presently reported study_rectangle) along western Bay of Bengal, other reports from Indian Ocean (circle - unconfirmed report, star-record from Sri Lanka) and known western most distribution range from Last et al. (2016a) (triangle) 


\section{RESULTS}

Family Dasyatidae

Hemitrygon Müller et Henle, 1838

Hemitrygon bennettii (Müller et Henle, 1841)

Figs. 2-6

Diagnosis. Medium-sized stingray with brownish to greenish-brown dorsal colouration and dorsal disc with median row of small denticles extending to tail, pair of lateral denticles patches on the scapular region, spines on tail larger; tail length $>2$ times DW, tail without any bands, tail with thin ventral fold (ribbon like), ventral tail fold origin behind the sting origin. Small denticles seen in the interspiracular region, mid-dorsal region, and shoulder regions of disc.

Description. (Figs. 2-6) Disc weakly rhombic, disc width nearly equal to disc length, disc width 1.03 times in disc length; dorsal surface with denticles and row of spines; ventral surface smooth. Body depressed, flat and slightly elevated trunk; snout short, broadly triangular or pointed, with anterior margin nearly straight to slightly concave, outer margins rounded; pre-oral snout length $22.1 \%$ in disc width, 0.5 in head length, 2.6 times mouth width. Pre-orbital snout length 0.24 in disc width, 1.8 in inter-orbital; pre-orbital snout width 0.6 in disc width; acute at apex with indistinct, triangular apical lobe; snout

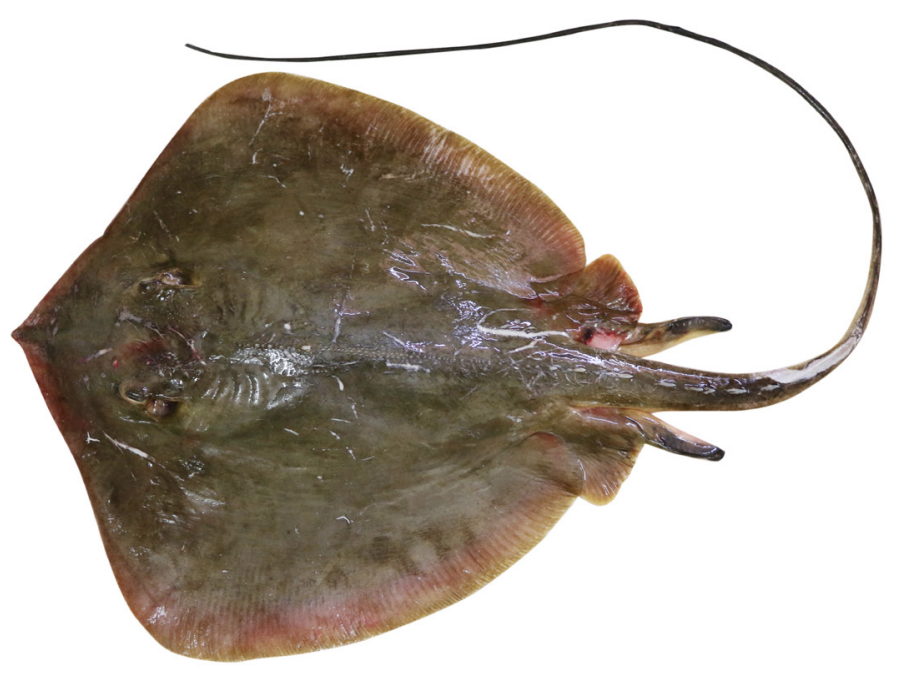

Fig. 2. Dorsal view of Hemitrygon bennettii., adult male, CMFRI V-D.1. (370 mm DW, Visakhapatnam, India, Bay of Bengal, 28 January 2017)

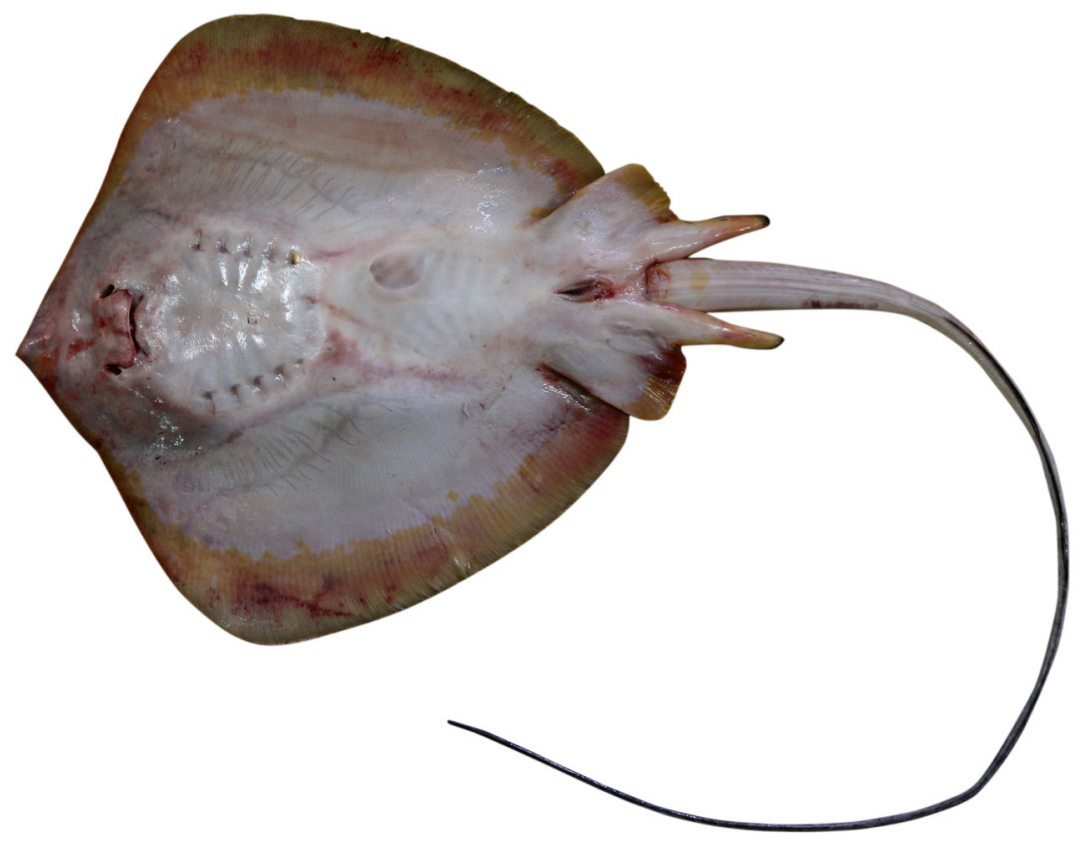

Fig. 3. Ventral view of Hemitrygon bennettii., adult male, CMFRI V-D.1. (370 mm DW, Visakhapatnam, India, Bay of Bengal, 28 January 2017) 
angle $110^{\circ}$. Greatest disc width slightly behind spiracles, towards anterior part of trunk. Head short, pointed at apex; pectoral fin broad, expanded to form trapezoidal disc, apex angular, posterior margin convex. Five gill slits; fifth gill slit smallest; first gill slit length $5.9 \%$ of head length; fifth gill slit length $4.2 \%$ of head length; distance between first pair of gill slits 2 times inter-narial width; distance between fifth gill slit wider than mouth width, 1.3 times inter-narial width. Head length $48.6 \%$ of disc width; pre-oral snout length 2.6 times mouth width, 2.2 times inter-narial width; inter-narial width 0.6 in pre-nasal distance, 2.8 times nostril length; nostril narrowly oval; nasal curtain skirt-like, slightly concave in middle; mouth arched, median portion of lower jaw, 3 oral papillae. Snout to maximum disc width $36 \%$ in disc width; pre-orbital length $24 \%$ in disc width. Interorbital space broad, weakly concave; eyes small, dorsolateral, slightly elevated and protruding; inter-orbital space with slope; eye diameter shorter than spiracle length; spiracle small; spiracle length 0.3 in pre-spiracular length. Pelvic weakly triangular, anterior and posterior margins almost straight or slightly concave, apices narrowly rounded. One large spine in centre of disc, preceded by 7-9 blunt spines; proceeded by ridge of blunt denticles leading to row of sharp spines from pectoral insertion (Fig. 5). Denticles progressively increasing in size till caudal sting. Spines erect or angular with strong basal region (hard). 8-9 large spines, unequal size and spacing; broad triangular base, broader in spines nearer to caudal sting. Tail elongate, slender, tail with low ventral tail fold; post-cloacal tail length 2.1 in disc width; tail base slightly depressed, broadly oval. Tail base width 1.5 times its depth; tapering gradually to sting base; slender and thin beyond spine origin, narrowly rounded in cross-section post spine. Caudal spine nearer to tail base; distance from pectoral insertion to caudal spine origin 2.6 times inter-spiracular width, 0.5 in DW; distance from cloaca to sting base 0.4 in DW, 0.4 in disc length. Tail with no markings; uniformly dark dorsally; ventrally pale. Ventral skin fold on tail, dorsal groove present. Ventral skin fold long, thin, length 0.6 in DW, 0.3 in post-cloacal tail length, origin well posterior after sting origin; distance from cloaca to sting origin 0.5 in pre-cloacal length. Ventral fold white/pale anteriorly, darkens posteriorly, ventral fold height progressively decreases. Clasper of adults moderately depressed, robust basally and tapering distally to blunt point; length $15.3 \%$ of DW. Clasper of adult male long and stout, oval in cross section and somewhat depressed. Clasper colour pale brown/blackish dorsally and posteriorly above, whitish below with yellow tip after preservation in formalin.

Barcode results. The COI sequence of $H$. bennettii from Visakhapatnam, India, western Bay of Bengal has been compared with COI sequences of $H$. bennettii from China, South China Sea, Malaysia, and Indonesia deposited in NCBI, GenBank ${ }^{*}$ grouped closest to $H$. bennettii from China, South China Sea, Malaysia, and Indonesia (Wang et al. 2012, Last and White 2013, Lim et al. 2015) showing $100 \%$ similarity $(n=11)$ (Fig. 7$)$. The neighbour- joining tree constructed using 27 sequences of COI of other Hemitrygon spp. showed distinct clustering among species (Fig. 7) with significant bootstrap values. In the COI tree, $H$. bennettii sequence of the specimen from Visakhapatnam (MH329420) clustered together with $H$. bennettii from Indonesia, China, and Malaysia. The tree topology was same when analyses were conducted using maximum likelihood, maximum parsimony, and neighbor-joining methods. The genetic divergence values (k2p distance) between $H$. bennettii and $H$. fluviorum, $H$. akajei, $H$. longicauda, $H$. izuensis, $H$. parvonigra, and H. laevigata were $3.2 \%, 4.1 \%, 4.8 \%, 7.4 \%, 10.7 \%$, and $11.4 \%$, respectively indicating that the species is closest to H. fluviorum followed by H. akajei.

\section{REMARKS AND DISCUSSION}

Hemitrygon bennettii is a nearshore species having a depth range of 25-36 m (Weigmann 2016). Trawlers operating off Visakhapatnam fish along the coast of India in depths down to $150 \mathrm{~m}$ and the majority of the major fishing grounds are found within the narrow continental shelf area in the region (Muktha et al. 2018). Since the specimen was landed by a trawler operating in Indian waters, the species is confirmed to have been caught within the Indian EEZ. Hemitrygon bennettii resembles $H$. akajei, however, H. akajei has a DW 1.1-1.2 (vs. 0.9-1.0 in H. bennettii). The presently reported $H$. bennettii material from the Indian coast had a slightly shorter tail (post-cloacal tail) (2.1 times DW), than mentioned as character for species by Last et al. (2016a) as 2.3-2.6 times DW and that by Nishida and Nakaya (1990) and Garman (1913) as $>3$ times DW. However, it may be noted that Müller and Henle (1841) in the original description had mentioned about shorter tails and Jordan and Richardson (1909) reported similar variable tail length for $H$. bennettii from Formosa and Zhang et al. (2010) from China reported tail lengths being 1.6-2.6 times DW. So, identification purely based on tail length may be unreliable for Hemitrygon due to its high degree of variability across regions. Genetic analysis and detailed morphometry have unambiguously confirmed the presence of $H$. bennettii in Indian waters. Since only a single specimen has been identified and recorded from Indian waters, this species may be considered to be rare in the region.

Several authors have reported the presence of Hemitrygon bennettii from Indian waters earlier; however, none of the authors has provided reference materials/collection details. This remains a large problem in elasmobranch taxonomy research in India due to which taxonomy of Indian elasmobranchs still remains largely unresolved. Part of this is due to the fact that no single Indian museum or repository either individually or all collections together hold specimens of all batoids reported from India, which hinders detailed and accurate elasmobranch taxonomic research in India. Assessment of the validity and distinctiveness of taxa requires sampling across the species range and examining materials reported in the same name, including from the type localities (Crandall et al. 2009, Rocha et al. 2014). The 


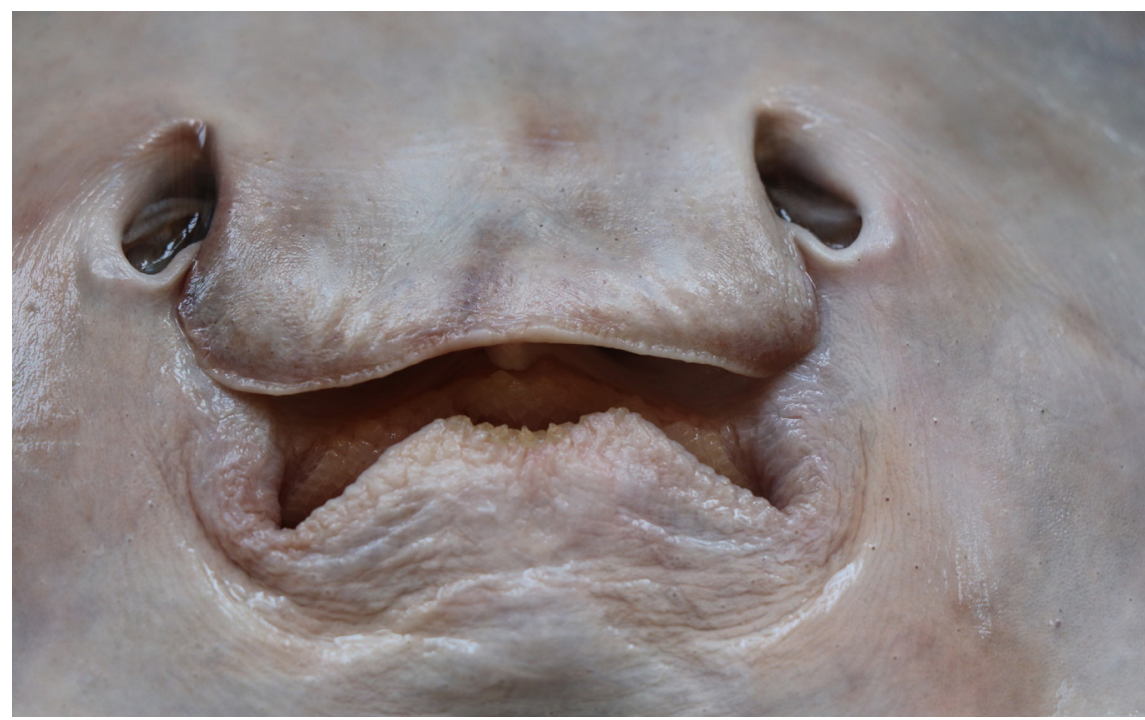

Fig. 4. Oronasal region of the Hemitrygon bennettii., adult male, CMFRI V-D.1. (370 mm DW, Visakhapatnam, India, Bay of Bengal, 28 January 2017)

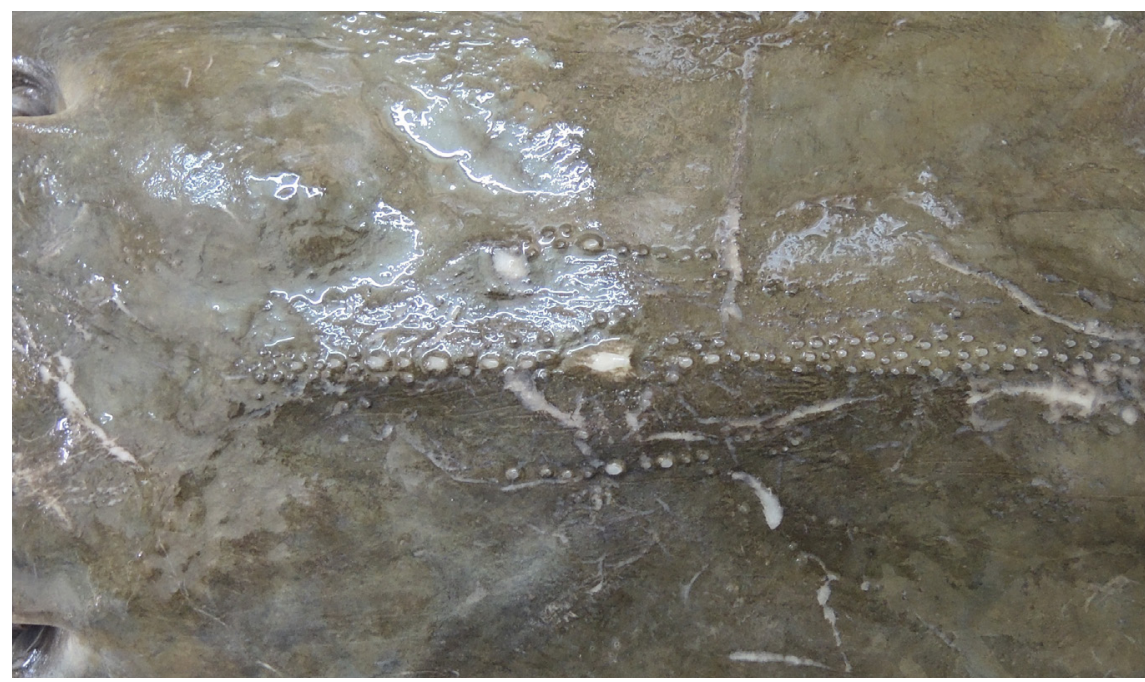

Fig. 5. Squamation on the central disc of Hemitrygon bennettii., adult male, CMFRI V-D.1. (370 mm DW, Visakhapatnam, India, Bay of Bengal, 28 January 2017)

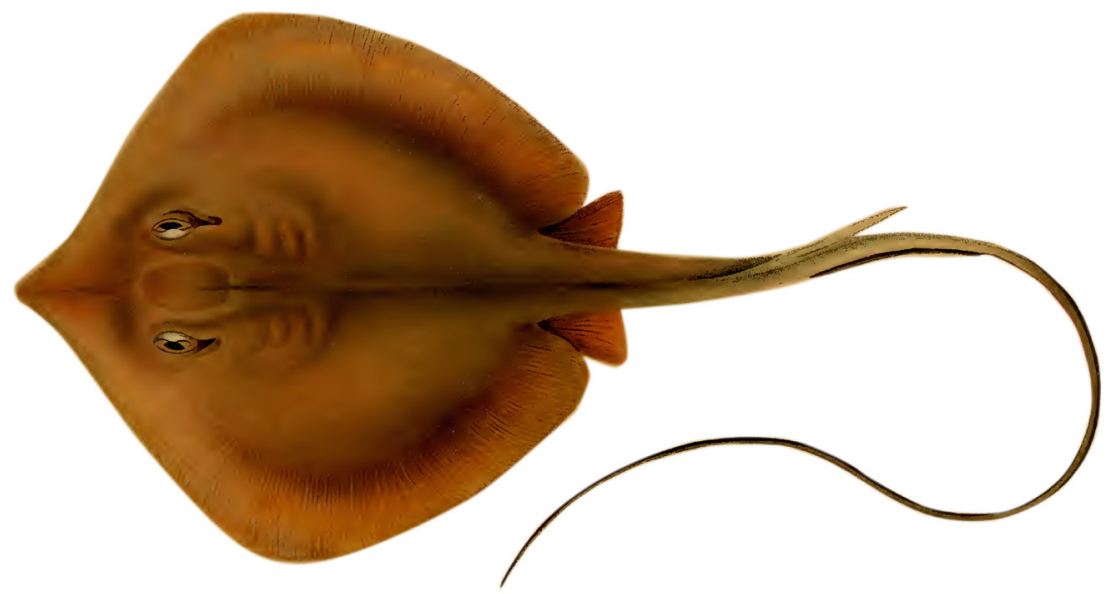

Fig. 6. Hemitrygon bennettii as Trygon bennettii from Müller et Henle (1841) 


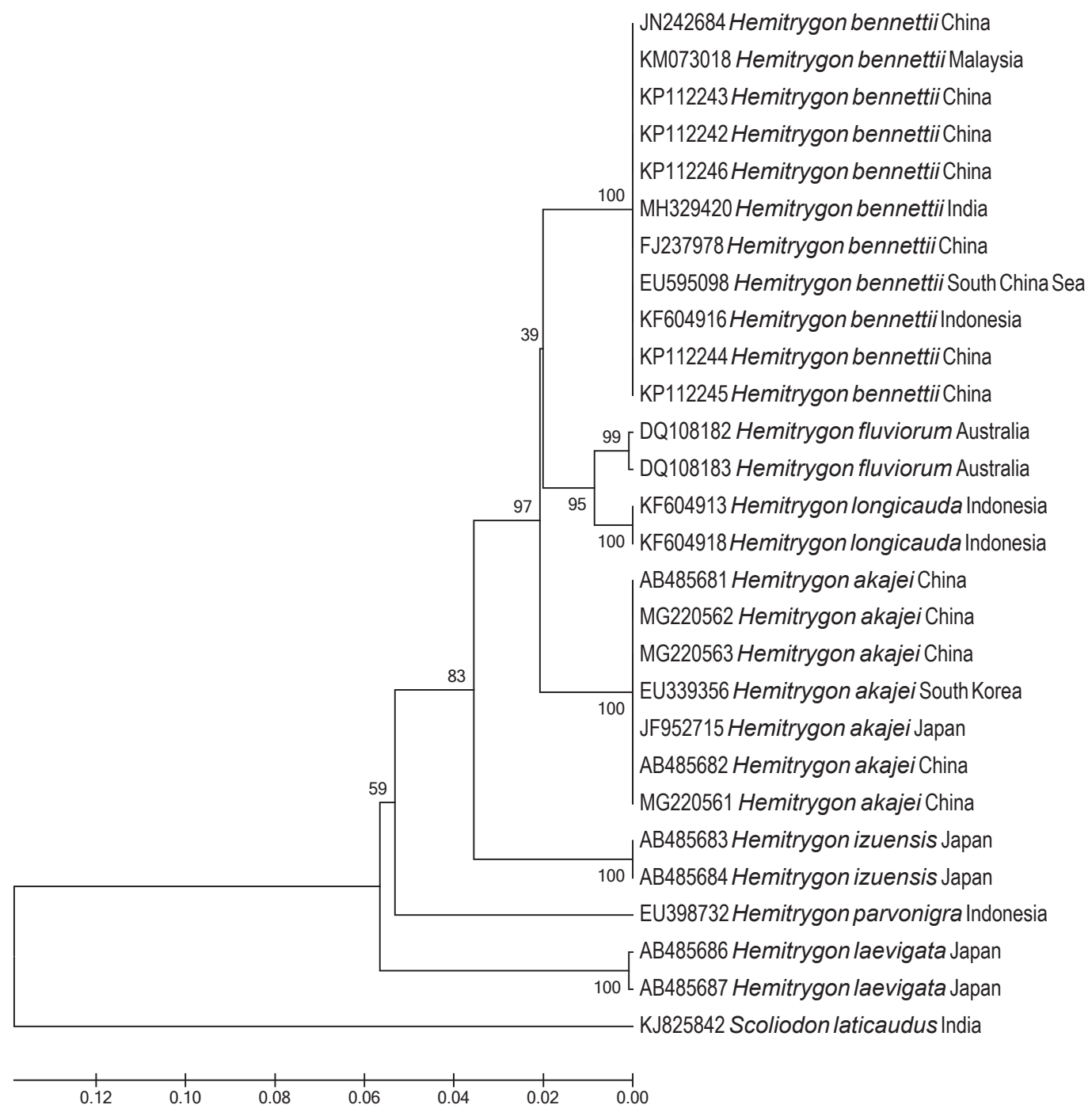

Fig. 7. Neighbour-joining tree of nucleotide sequence divergence of the COI gene following the Kimura two-parameter model (K2P) generated by NCBI database for available Hemitrygon species and Hemitrygon bennettii from India (MH32920)

need for having an exclusive national collection/repository of native marine taxa is therefore of prime importance and critical for expanding and improving marine fish taxonomy/research (and conservation) not only in India, but also in the larger Indo-Pacific region where many countries have limited access to museum specimens or international travel grants for visiting foreign museums for studies. Better collections and specimen repositories could support improved biodiversity research in the region. Most countries in the Indian Ocean region which do not have a good reference collection are in the process of acquiring larger national collections as part of the Census of Marine Life or by understanding the importance of having own/ national collections.

\section{ACKNOWLEDGEMENTS}

Scientist-In-Charge, ICAR-CMFRI Visakhapatnam $\mathrm{RC}$ is acknowledged for the facilities. Help provided by Jasmin F., Manas H.M., Jishnudev M.A, Bhaskar Rao, and Venkateswarulu V. of Visakhapatnam RC of ICARCMFRI during field visits is acknowledged. Authors are grateful to Biodiversity Heritage Library (BHL) for free access to their excellent collection of rare books. This study was carried out under the ICAR-CMFRI project DEM/ELS/11.

\section{REFERENCES}

Akhilesh K.V., Bineesh K.K., Gopalakrishnan A., Jena J.K., Basheer V.S., Pillai N.G.K. 2014. Checklist of chondrichthyans in Indian waters. Journal of the Marine Biological Association of India 56 (1): 109120. DOI: $10.6024 / \mathrm{jmbai} .2014 .56 .1 .01750 \mathrm{~s}-17$

Anonymous 2018. Catalogue of Life. The catalogue of life partnership. [Accessed on 16 July 2018.] DOI: $10.15468 / \mathrm{rffz} 4 \mathrm{x}$

Assadi H., Dehghani P.R. 1997. Atlas of the Persian Gulf and the Sea of Oman fishes. Iranian Fisheries Research and Training Organization, Tehran, Iran. 
Crandall K.A., Robison H.W., Buhay J.E. 2009. Avoidance of extinction through nonexistence: The use of museum specimens and molecular genetics to determine the taxonomic status of an endangered freshwater crayfish. Conservation Genetics 10 (1): 177-189. DOI: $10.1007 / \mathrm{s} 10592-008-9546-9$

Day F. 1878. The fishes of India; being a natural history of the fishes known to inhabit the seas and fresh waters of India, Burma, and Ceylon. Volume I, text. Volume II. Atlas-Containing 198 plates, Bernard Quaritch, London, England. DOI: 10.5962/bhl.title.62705

Day F. 1889. Fishes.-Vol. II. In: Blanford W.T. (ed.) The fauna of British India, including Ceylon and Burma. Taylor and Francis, London, England. DOI: 10.5962/ bhl.title. 100755

Fricke R., Eschmeyer W.N., van der Laan R. (eds.) 2018. Catalog of fishes: Genera, species, references. California Academy of Sciences, San Francisco, USA. [Accessed on 2 October 2018.] http://researcharchive. calacademy.org/research/ichthyology/catalog/ fishcatmain.asp

Froese R., Pauly D. (eds.) 2018. FishBase. [Version 02/2018] http://www.fishbase.org

Folmer O., Black M., Hoeh W., Lutz R., Vrijenhoek R. 1994. DNA primers for amplification of mitochondrial cytochrome $c$ oxidase subunit I from diverse metazoan invertebrates. Molecular Marine Biology and Biotechnology 3 (5): 294-299.

Garman S. 1913. The Plagiostomia (sharks, skates, and rays). Memoirs of the Museum of Comparative Zoölogy at Harvard College 36: 1-528 and 77 plates.

Jacobsen I.P., Bennett M.B. 2009. A taxonomic review of the Australian butterfly ray Gymnura australis (Ramsay \& Ogilby, 1886) and other members of the family Gymnuridae (Order Rajiformes) from the IndoWest Pacific. Zootaxa 2228: 1-28. DOI: 10.5281/ zenodo. 190240

Jordan D.S., Richardson R.E.1909. A catalogue of the fishes of the island of Formosa, or Taiwan, based on the collections of Dr. Hans Sauter. Memoirs of the Carnegie Museum 4 (4): 159-204, Pls. 63-74.

Last P.R., Manjaji-Matsumota B.M., Naylor G.J.P., White W.T. 2016a. Stingrays, Family Dasyatidae. Pp. 522-618. In: Last P.R., White W.T., de Carvalho M.R., Séret B., Stehmann M.F.W., Naylor G.J.P (eds.) Rays of the world. CSIRO Publishing, Melbourne, Australia.

Last P.R., Naylor G.J.P., Manjaji-Matsumoto B.M. 2016b. A revised classification of the family Dasyatidae (Chondrichthyes: Myliobatiformes) based on new morphological and molecular insights. Zootaxa 4139 (3): 345-368. DOI: 10.11646/zootaxa.4139.3.2

Last P.R., White W.T. 2013.Two new stingrays (Chondrichthyes: Dasyatidae) from the eastern Indonesian Archipelago. Zootaxa 3722 (1): 1-21. DOI: 10.11646/zootaxa.3722.1.1

Lim K.C., Lim P.-E., Chong V.C., Loh K.-H. 2015. Molecular and morphological analyses reveal phylogenetic relationships of stingrays focusing on the family Dasyatidae (Myliobatiformes). PLoS ONE 10 (5): e0129411. DOI: 10.1371/journal.pone.0120518

Misra K.S. 1947. A check list of the fishes of India, Burma, and Ceylon. Part I. Elasmobranchii and Holocephali. Records of the Indian Museum 45: 1-46.

Misra K.S. 1952. An aid to the identification of the fishes of India, Burma and Ceylon. I. Elasmobranchii and Holocephali. Records of the Indian Museum 49 (1): 89-137.

Misra K.S. 1969. Pisces (Second edition) Vol. 1. Elasmobranchii and Holocephali. In: Roonwal M.L. (ed.) The fauna of India and the adjacent countries. Zoological Survey of India, Government of India Press, Faridabad, India.

Muktha M., Akhilesh K.V., Sandhya S., Jasmin F., Jishnudev M.A., Kizhakudan S.J. 2018. Re-description of the longtail butterfly ray, Gymnura poecilura (Shaw, 1804) (Gymnuridae: Myliobatiformes) from Bay of Bengal with a neotype designation. Marine Biodiversity 48 (2): 1085-1096. DOI: $10.1007 / \mathrm{s} 12526-016-0552-8$

Müller J., Henle J. 1841. Systematische Beschreibung der Plagiostomen. Verlag von Veit und Comp., Berlin, Kingdom of Prussia. DOI: 10.5962/bhl.title.6906

Nishida K., Nakaya K. 1990. Taxonomy of the genus Dasyatis (Elasmobranchii, Dasyatididae) from the north Pacific. Pp. 327-345. In: Pratt H.L., Gruber S.H., Taniuchi T. (eds.) Elasmobranchs as living resources: Advances in the biology, ecology, systematics, and the status of the fisheries. NOAA Technical Report 90.

Rocha L.A., Aleixo A., Allen G., Almeda F., Baldwin C.C., Barclay M.V.L., Bates J.M., Bauer A.M., Benzoni F., Berns C.M., Berumen M.L., Blackburn D.C., Blum S., Bolaños F., Bowie R.C.K., Britz R., Brown R.M., Cadena C.D., Carpenter K., Ceríaco L.M., Chakrabarty P., Chaves G., Choat J.H., Clements K.D., Collette B.B., Collins A., Coyne J., Cracraft J., Daniel T., de Carvalho M.R., de Queiroz K., Di Dario F., Drewes R., Dumbacher J.P., Engilis A.jr., Erdmann M.V., Eschmeyer W., Feldman C.R., Fisher B.L., Fjeldså J., Fritsch P.W., Fuchs J., Getahun A., Gill A., Gomon M., Gosliner T., Graves G.R., Griswold C.E., Guralnick R., Hartel K., Helgen K.M., Ho H., Iskandar D.T., Iwamoto T., Jaafar Z., James H.F., Johnson D., Kavanaugh D., Knowlton N., Lacey E., Larson H.K., Last P., Leis J.M., Lessios H., Liebherr J., Lowman M., Mahler D.L., Mamonekene V., Matsuura K., Mayer G.C., Mays H.jr., McCosker J., McDiarmid R.W., McGuire J., Miller M.J., Mooi R., Mooi R.D., Moritz C., Myers P., Nachman M.W., Nussbaum R.A., Foighil D.Ó., Parenti L.R., Parham J.F., Paul E., Paulay G., Pérez-Emán J., Pérez-Matus A., Poe S., Pogonoski J., Rabosky D.L., Randall J.E., Reimer J.D., Robertson D.R., Rödel M.-O., Rodrigues M.T., Roopnarine P., Rüber L., Ryan M.J., Sheldon F., Shinohara G., Short A., Simison W.B., Smith-Vaniz W.F., Springer V.G., Stiassny M., Tello J.G., Thompson C.W., Trnski 
T., Tucker P., Valqui T., Vecchione M., Verheyen E., Wainwright P.C., Wheeler T.A., White W.T., Will K., Williams J.T., Williams G., Wilson E.O., Winker K., Winterbottom R., Wit C.C. 2014. Specimen collection: An essential tool. Science 344 (6186): 814-815. DOI: 10.1126/science.344.6186.814 Smith W.D., Bizzarro J.J., Richards V.P., Nielsen J., Márquez-Farías F., Shivji M.S. 2009. Morphometric convergence and molecular divergence: The taxonomic status and evolutionary history of Gymnura crebripunctata and Gymnura marmorata in the eastern Pacific Ocean. Journal of Fish Biology 75 (4): 761783. DOI: $10.1111 /$ j.1095-8649.2009.02300.x

Talwar P.K., Kacker R.K. 1984. Commercial sea fishes of India. Zoological Survey of India, Calcutta, India.

Valenti S.V. 2016. Hemitrygon bennetti. The IUCN Red List of Threatened Species 2016: e.T161533A104114664. [Downloaded on 27 February 2018.] DOI: 10.2305/IUCN.UK.2016-3.RLTS. T161533A104114664.en
Vossoughi G.H., Vosoughi A.R. 1999. Study of batoid fishes in northern part of Hormoz Strait, with emphasis on some species new to the Persian Gulf and Sea of Oman. Indian Journal of Fisheries 46 (3): 301-306.

Wang Z.-D., Guo Y.-S., Liu X.-M., Fan Y.-B., Liu C.-W. 2012. DNA barcoding South China Sea fishes. Mitochondrial DNA 23 (5): 405-410. DOI: 10.3109/19401736.2012.710204

Weigmann S. 2016. Annotated checklist of the living sharks, batoids and chimaeras (Chondrichthyes) of the world, with a focus on biogeographical diversity. Journal of Fish Biology 88 (3): 837-1037. DOI: $10.1111 / \mathrm{jfb} .12874$

Zhang J., Yamaguchi A., Zhou Q., Zhang C. 2010. Rare occurrences of Dasyatis bennettii (Chondrichthyes: Dasyatidae) in freshwaters of southern China. Journal of Applied Ichthyology 26 (6): 939-941. DOI: 10.1111/j.1439-0426.2010.01525.x

Received: 17 May 2018 Accepted: 8 October 2018 Published electronically: 15 March 2019 